\title{
Absent friends: common law constitutionalism and the Northern Ireland Bill of Rights debate \\ TIM CUNNINGHAM ${ }^{1}$
}

PhD Student, Transitional Justice Institute, University of Ulster

\section{The Bill of Rights debate in Northern Ireland - an overview}

$I^{n}$ n November 2009, the then Secretary of State for Northern Ireland, Shaun Woodward issued a consultation paper on the way forward for a Bill of Rights for Northern Ireland. ${ }^{2}$ To say that these proposals were greeted with a degree of scepticism would be something of an understatement. ${ }^{3}$ Significantly, however, the timing of the Northern Ireland Office (NIO) consultation document meant that progress on this issue was circumscribed by the dissolution of Parliament.

The new Conservative-Liberal Democrat government has given a commitment to establish a commission to investigate the creation of a British Bill of Rights that incorporates and builds on "all our obligations under the European Convention on Human Rights, ensures that these rights continue to be enshrined in British law, and protects and extends British liberties". ${ }^{4}$ There is also a general commitment to continue to promote peace, stability and economic prosperity in Northern Ireland, standing firmly behind the agreements negotiated and institutions they establish. ${ }^{5}$

Where exactly this leaves the local Bill of Rights debate, and indeed the 2009 proposals, is therefore a matter for some conjecture. It is worth noting that, while in opposition, the Conservative Party concluded that the proposals contained in the November 2009

1 This article began as a thesis that was submitted as part of the requirements for the LLM in international human rights at Queen's University Belfast. Particular thanks go to Professor Brice Dickson of QUB, my thesis supervisor; Professor Christine Bell, Director of the Transitional Justice Institute, University of Ulster; and Aideen Gilmore, Deputy Director of the Committee on the Administration of Justice; all of whom provided valuable comments on the development of this article.

2 A Bill of Rights for Northern Ireland: Next steps (Belfast: NIO, November 2009).

3 The consultation document has been rejected by the NIHRC which has described it as an "inadequate response to what should be in a Bill of Rights for Northern Ireland", press release, 17 February 2010, available at www.nihrc.org/. Professor Christopher McCrudden, a leading commentator on this issue, has described the proposals as "not only disappointing, but positively dangerous", Irish News, 16 February 2010, p. 14, while the Committee on the Administration of Justice (CAJ) has stated that the consultation document has "generated concern and anger among a broad swathe of civil society who have been engaging in good faith in the debate and process about a Bill of Rights for Northern Ireland over the course of the past twelve years" (submission to A Bill of Rights for Northern Ireland: Next steps, n. 2 above, available at www.caj.org.uk/).

4 “The Coalition: Our programme for government", Cabinet Office, Ref. 401238/0510, May 2010, www.cabinetoffice.gov.uk/409088/pfg_coalition.pdf, p. 11.

5 Ibid., p. 28. 
document were "very sensible" and posed questions for future debate. ${ }^{6}$ It is the prediction of this author that deliberations on the best way forward for protecting rights specifically within the context of the particular circumstances of Northern Ireland will continue throughout the life of this Parliament, regardless of any developments relating to a British Bill of Rights and the extension and protection of "British liberties". It is the intention of this article to seek to inform these future deliberations.

It is worth recalling that the latest current phase of the Bill of Rights debate commenced in December 2008 when the Northern Ireland Human Rights Commission (NIHRC) submitted advice to the Secretary of State for Northern Ireland on the way forward for a Bill of Rights for Northern Ireland. ${ }^{7}$ This article will focus on those proposals, as well as a number of other aspects of the wider Bill of Rights debate, in order to examine the extent to which considerations of common law constitutionalism have been absent from the wider deliberations on this issue.

It is important to be clear about the purpose of this article. It is not to argue that Northern Ireland does not need a Bill of Rights - in fact this author would largely agree with the substantive proposals that the NIHRC submitted to the Secretary of State in December 2008. Neither will this article suggest that future developments within the domestic courts are likely to provide an adequate alternative to a Bill of Rights for Northern Ireland. This article will, however, argue that the extensive deliberations that have taken place as part of the wider Bill of Rights debate have largely omitted developments within the domestic courts with respect to common law rights protection. In particular, it will argue that one consequence of this omission is that the impression has been created that international human rights instruments, including the European Convention on Human Rights (ECHR) (via the Human Rights Act 1998) represent the sole remedies for those challenging an alleged human rights violation in the domestic courts.

\section{The evolution of the Bill of Rights debate in Northern Ireland}

It is first necessary to examine briefly the evolution of the Northern Ireland Bill of Rights debate in order to identify the extent of the problem. The Belfast Agreement reached in multi-party talks in 1998 mandated the new NIHRC to:

consult and to advise on the scope for defining, in Westminster legislation, rights supplementary to those in the European Convention on Human Rights, to reflect the particular circumstances of Northern Ireland, drawing as appropriate on international instruments and experience. These additional rights to reflect the principle of mutual respect for the identity and ethos of both communities and parity of esteem and - taken together with the European Convention on Human Rights - to constitute a Bill of Rights for Northern Ireland. ${ }^{8}$

6 D Grieve QC MP, Shadow Justice Secretary, "What price justice?", lecture to the Northern Ireland Bar, 4 February 2010.

7 NIHRC, Advice to the Secretary of State on a Bill of Rights for Northern Ireland (Belfast: NIHRC, December 2008). While this document might be seen to have ushered in the "latest phase" of the debate, discussions about a Bill of Rights for Northern Ireland have been running since the 1970s, see e.g. A Bill of Rights for Northern Ireland Through the Years - the views of the political parties (Belfast: CAJ, July 2003), available at www.caj.org.uk/publications.

8 The Belfast Agreement: An agreement reached at the multi-party talks on Northern Ireland, Command Paper Cm 3883 (1998), Strand 6, para. 4. 
The first substantive draft advice produced by the NIHRC to fulfil its mandate appeared in $2001,{ }^{9}$ with a follow-up document in $2004 .{ }^{10}$ The 2001 document was largely based upon the reports of a number of working groups which comprised a range of experts tasked with identifying particular issues for attention in the proposed Bill of Rights. In addition, a working paper, Taking Forward a Bill of Rights for Northern Ireland, ${ }^{11}$ was produced by members of the commission, in February 2005, to assist the newly appointed commissioners in assessing the progress made.

The NIHRC's work on this issue has included a range of workshops, conferences, information events and public and private meetings with organisations, individuals and political parties. From January 2006 to November 2008 alone, the NIHRC convened 54 meetings of an internal Bill of Rights Working Group and held seven weekend seminars. ${ }^{12}$ During this period, the NIHRC also met with individual political party representatives in the Northern Ireland Assembly on 18 occasions and met with the human rights spokespersons from the major parties at Westminster. ${ }^{13}$ The NIHRC also met with NIO officials, the Secretary of State, UK government ministers, the Taoiseach, the Minister for Foreign Affairs and Irish government officials. ${ }^{14}$

In addition to the work of the NIHRC, thinking on this issue was also developed by a number of other elements within civil society. Following the lack of agreement around the publication of the 2004 NIHRC document, the NIO established a Bill of Rights Forum, where, from December 2006 until March 2008, 14 political representatives sat down with 14 civil society representatives to try to work out consensus proposals under an independent chair. ${ }^{15}$ The NIHRC welcomed the establishment of the forum and, while it remained independent from the process, observed the forum's proceedings. ${ }^{16} \mathrm{~A}$ final report by the forum was submitted to the NIHRC on 31 March 2008, ${ }^{17}$ and, according to the NIHRC, its deliberations "paid rigorous attention to the proposals contained in the Forum Report, with each considered in detail". ${ }^{18}$ In addition to the forum, a Human Rights Consortium was set up in 2000, again, independent of the NIHRC, which developed its own programme of activities that included research, education and lobbying. In early 2008, the consortium ran a publicity campaign to raise awareness of a Bill of Rights for Northern Ireland and the NIHRC met regularly with the consortium during this time. ${ }^{19}$

9 NIHRC, Making a Bill of Rights for Northern Ireland: A consultation by the NIHRC (Belfast: NIHRC 2001).

10 NIHRC, Progressing a Bill of Rights for Northern Ireland (Belfast: NIHRC, April 2004).

11 NIHRC, Taking Forward a Bill of Rights for Northern Ireland (Belfast: NIHRC 2005).

12 NIHRC, Advice, n. 7 above, p. 11.

13 Ibid.

14 Ibid.

15 Ibid.

16 Ibid., p. 13.

17 Bill of Rights Forum (BORF), Bill of Rights Forum Final Report: Recommendations to the NIHRC on a Bill of Rights for Northern Ireland (Belfast: BORF 2008).

18 NIHRC, Advice, n. 7 above, p. 13.

19 Ibid. The Human Rights Consortium has continued to have a significant advocacy role in the Bill of Rights debate, currently organising a quite extensive publicity campaign opposing the NIO proposals issued in November 2008. See www.billofrightsni.org/support/index.php. 


\section{The Northern Ireland Bill of Rights debate and the common law}

What is significant for the purposes of this article is that, in spite of the volume of materials and discussions that these various processes generated, there has been little mention of how common law rights might assist, or indeed complement, the development of a Bill of Rights for Northern Ireland. Indeed, virtually the only references to the common law at all in the documents issued by the NIHRC in 2001, 2004 and 2008 relate to interpretation clauses. ${ }^{20}$

An exception to this general trend did occur in the 2001 document which at least acknowledged the existence of one common law right and how this could be linked to the NIHRC's proposals. This document proposed a number of clauses for the Bill of Rights regarding the participation rights of children which included a requirement that:

The State shall ensure to every child the right to express his or her views freely in all matters concerning him or her. The State undertakes to consider such views and to give them due weight in accordance with the age and maturity of the child. ${ }^{21}$

The document went on to propose an additional clause which required that:

every child has the right to participate effectively, either directly or indirectly through an independent representative, in all proceedings affecting him or her, whether administrative or judicial, in public or private law. Every child has the right of access to the law and to legal representation. ${ }^{22}$

The NIHRC's proposals explained that the first of the clauses above reflected the terms of Article 12 of the UN Convention on the Rights of the Child and also, significantly:

the common law principle that children with the requisite understanding may be entitled to make their own decisions on issues which directly affect them, subject to the overriding "best interests" principle. ${ }^{23}$

The document further stated that the second clause was designed to guarantee that the principle in question:

which is already accepted in practice under the common law and under most children's legislation, is adhered to in all formal legal and administrative proceedings. 24

Significantly, however, by the publication of the final advice to the Secretary of State in December 2008, even this modest reference to common law principles had been omitted. The 2008 document continued to propose a separate section on children's rights, although with some modifications on the 2001 proposals. In terms of participation of children, the two clauses identified above had been replaced by a single clause which stated provisions should be drafted to ensure that:

Public authorities must take all appropriate measures to ensure the right of every child to be informed of their rights and to have his or her views respected, considered and given due regard in all matters affecting the child, taking into consideration the child's age, level of understanding and evolving capacities. 25

20 NIHRC, Making a Bill of Rights, n. 9 above, p. 93; NIHRC, Progressing a Bill of Rights, n. 10 above, p. 22; NIHRC, Advice, n. 7 above, p. 57.

21 NIHRC, Making a Bill of Rights, n. 9 above, p. 65.

22 Ibid.

23 Ibid.

24 Ibid.

25 Ibid. 
In relation to the explanation provided of how the NIHRC had reached its recommendation, the document merely alluded to drawing upon the authority of Article 12 of the UN Convention on the Rights of the Child, along with a reference to the fact that this provision does not appear in the ECHR. ${ }^{26}$ At a stroke, therefore, what had been identified as an existing common law principle in the 2001 document had, in effect, become a proposed additional right that implicitly derived its authority solely from the UN Convention on the Rights of the Child by the time of the 2008 advice.

\section{The common law and the Bill of Rights debate beyond the NIHRC}

Looking beyond the work of the NIHRC, it is worth noting that the final report issued by the Bill of Rights Forum, which ran to some 250-plus pages, omitted any reference to the common law whatsoever, ${ }^{27}$ somewhat mirroring the approach taken by civil society organisations in submitting responses to the NIHRC's consultations. ${ }^{28}$

A similar approach is evident with respect to the more academic discussions which took place in relation to this issue. For example, in the Special Double Issue on the Proposed Bill of Rights for Northern Ireland of the NILQ, references to the common law, or indeed common law constitutionalism or judicial activism, are notable by their absence. ${ }^{29}$ Harvey would appear to be the sole contributor making reference to judicial activism, but that is within the context of a single reference to the United States and the Northern Ireland Bill of Rights in comparative perspective. ${ }^{30}$ Harvey does make one other reference to the judiciary, although that is within the context of his argument for a human rights court, which, he suggested, could dispel concerns in a context where "distrust of the judiciary is a fact". 31

It is worth noting that this special Bill of Rights edition of the NILQ contained articles on the wider need for a Bill of Rights for Northern Ireland: ${ }^{32}$ children's rights; ${ }^{33}$ equality issues; ${ }^{34}$ issues of criminal justice; ${ }^{35}$ language issues; $; 6$ victims' rights; $;{ }^{37}$ education rights; 38 economic, social and cultural rights; 39 the implementation of a Bill of Rights; 40 and the importance of a Bill of Rights as a process. ${ }^{41}$ Certainly, looking at the materials, one might be forgiven for believing that rights protection is located exclusively within international human rights instruments.

26 NIHRC, Advice, n. 7 above, p. 134.

27 BORF, Final Report, n, 17 above.

28 NIHRC, Summary of Submissions on a Bill of Rights (Belfast: NIHRC, July 2003).

29 Special Double Issue on the Proposed Bill of Rights for Northern Ireland (2001) 52 NILQ 229-406.

30 C Harvey, "The implementation of a Bill of Rights for Northern Ireland" (2001) 52 NILQ 342, at 358.

31 Ibid., p. 370.

32 S Livingstone, "The need for a Bill of Rights in Northern Ireland" (2001) 52 NILQ 269.

33 U Kilkelly, “Children's rights in the Bill of Rights: meeting or exceeding international standards?” (2001) 52 NILQ 286.

34 M Beirne, "Equality issues" (2001) 52 NILQ 296.

35 P Mageean, "Issues of criminal justice" (2001) 52 NILQ 303.

36 C O'Murchadha and L Reynolds, "A Bill of Rights for Northern Ireland: language issues in context" (2001) 52 NILQ 309.

37 B Gormally, "Victims and the Bill of Rights" (2001) 52 NILQ 316.

38 E Craig and L Lundy, "Education rights in the Bill of Rights" (2001) 52 NILQ 325.

39 L Allamby, "Economic, social and cultural rights" (2001) 52 NILQ 335.

40 Harvey, "The implementation", n. 30 above, at 342.

41 R Murray "The importance of a Bill of Rights in Northern Ireland as a process: comparative reflections from South Africa” (2001) 52 NILQ 385. 


\section{Judges and the protection of rights - a brief overview}

In some senses, perhaps, the general neglect of the role of the courts in developing rights protection under the common law might be somewhat unsurprising. Writing in 2001, Harvey referred to the "fact" of distrust of the judiciary's capacity to deliver the goods when it comes to protecting rights, something which he believed necessitated the establishment of a human rights court. ${ }^{42}$

Livingstone was critical of the role of the judiciary in securing rights protection during the context of the Northern Ireland conflict and concluded that judges might not be trusted when in comes to interpreting a Bill of Rights. ${ }^{43}$ Beyond the particular circumstances of the Northern Ireland conflict, Ewing and Gearty delivered an even more damning critique of the judicial role in relation to rights protection. They argued that many of the restrictions on political freedom came not from legislation but judge-made initiatives authorising the extension of executive power. They concluded that the "harsh reality is that we need to be protected by parliament from the courts". 44

It is, perhaps, also worth noting that while a number of commentators have identified difficulties with respect to the role of the judiciary in protecting rights, a range of reasons have been suggested for those difficulties - beyond merely a natural aversion on the part of the judiciary towards rights claimants. Some commentators have argued for example that the dualist/monist structural divide has created difficulties with respect to implementing international human rights obligations at the domestic level. ${ }^{45}$

Certainly, in recent years, assessments of the role of the judiciary in relation to the protection of rights have been somewhat more favourable. ${ }^{46}$ Dickson has revisited the theme explored earlier by Livingstone concluding that there is now a "freshness and sophistication" in the judicial reasoning apparent in the last 10 years which was not apparent before that. ${ }^{47}$ Certainly, Dickson did not unequivocally endorse all the Law Lords' reasonings - he found the ruling in McKerr to be "lame". 48 Significantly however, for the purposes of this article, Dickson "largely" agrees with the analysis provide by Livingstone of the earlier cases. ${ }^{49}$

\section{The common law constitutional difficulty}

In this context, it is important to acknowledge that a significant body of work has developed since the 1990 s at UK level around the extent to which the judiciary can, or

42 Harvey, "The implementation", n. 30 above, at 370.

43 S Livingstone, "The House of Lords and the Northern Ireland conflict" (1994) 57 Modern Law Review 333.

44 K Ewing and C Gearty, Freedom under Thatcher: Civil liberties in modern Britain (Oxford: OUP 1990), pp. $270-1$.

45 Anthony has argued that the House of Lords in McKerr [2004] UKHL 12, by holding that no investigation could be ordered because the Human Rights Act 1998 did not apply to events that pre-date its coming into force, effectively "placed at one remove from the ECHR events that had already been said by the European Court of Human Rights to lack full and effective investigation". G Anthony, "Human rights in Northern Ireland after Re McKerr" (2005) 11 European Public Law 5. Anthony and Mageean locate the origin of this difficulty back at the doctrine of parliamentary sovereignty which places domestic human rights law generally at one remove from international norms: G Anthony and P Mageean, "Habits of mind and 'truth-telling': Article 2 ECHR in post-conflict Northern Ireland” in J Morison et al. (eds), Judges, Transition and Human Rights (Oxford: OUP 2007).

46 B Dickson, "The House of Lords and the Northern Ireland conflict - a sequel” (2006) 69 Modern Law Review 383; B Dickson, "Safe in their hands? Britain's Law Lords and human rights" (2006) 26 Legal Studies 329.

47 Ibid., at 414.

48 Ibid.

49 Ibid., at 384. 
indeed should, seek to curb the actions of the executive and the legislature. ${ }^{50}$ It is the extent to which the final authority delivered by a court may impinge upon the actions of Members of Parliament or ministers of the Crown, however, that has generated what Dickson has referred to as a "prolific and fierce debate". 51

The crux of this debate has tended to focus on the extent to which judicial findings may impinge upon Dicey's central proposition that "the sovereignty of Parliament is, from a legal point of view, the dominant characteristic of our political constitution". 52 According to Dicey, Parliament has the right to make or unmake any law whatever: and, further, no person or body is recognised as having a right to override or set aside the legislation of Parliament. 53 Leyland argues that, while constitutional practice has moved "steadily" towards a system of review of the constitutionality of Acts of the Westminster Parliament, Diceyan notions of the sovereignty of Parliament still retain a high degree of influence and Acts of Parliament remain sovereign. ${ }^{54}$

A classic interpretation of this principle was expounded recently in the Northern Ireland High Court. ${ }^{55}$ The case related to a challenge brought against the decision by the Northern Ireland Court Service to refuse the applicant permission to lodge a court application for an occasional liquor licence in the Irish language. ${ }^{56}$ One of the grounds for the challenge was that the Administration of Justice (Language) Act (Ireland) 1737 requires that in Northern Ireland all court proceedings and associated documents be in the English language. ${ }^{57}$ It was argued by the applicant that this Act was incompatible with the European Charter for Regional and Minority Languages and as such was in breach of the applicant's legitimate expectation that the UK would act consistently with its international legal obligations under the charter. ${ }^{58}$

Dismissing the application, Treacy J ruled that the distinction between international law and domestic law was long accepted by the courts in the United Kingdom and that, where it is intended to give domestic effect to obligations arising from international treaties, the method of achieving this is by incorporating the relevant treaty into domestic law. ${ }^{59}$ For Treacy, this:

well established legal position reflects the constitutional principle that in the UK the Executive does not have lawmaking powers unless these are conferred upon it by Parliament. The ratification of an international treaty such as the Charter is an Executive action effected under prerogative power and involves no delegation

50 See, for example, R Dworkin, Justice in Robes (London: Harvard UP 2006); M Elliott, "The sovereignty of Parliament, the hunting ban and the Parliament Acts" (2006) 65 Cambridge Law Journal 1; D Jenkins, "Common law declarations of unconstitutionality" (2009) 7 International Journal of Constitutional Law 183; J Jowell, "Parliamentary sovereignty under the new constitutional hypothesis" (2006) Public Law 562-80.

51 B Dickson, "The role of judges in developing constitutions" (2006) 57 NILQ 332, at 332; see also, B Dickson (ed.), Judicial Activism in Common Law Supreme Courts (Oxford: OUP 2007).

52 A Dicey, Introduction to the Study of the Law of the Constitution 8th edn, reprint (Indianapolis: Liberty Classics 1982), p. xxxvi.

53 Ibid.

54 P Leyland, "Administrative law and human rights" in P Leyland and G Anthony (eds), Textbook on Administrative Law (Oxford: OUP 2008), p. 182.

55 In the Matter of an Application by Caoimbin MacGiolla Cathain for Judicial Review [2009] NIQB 66.

56 Ibid.

57 Ibid.

58 Ibid.

59 Ibid., para. 32 . 
of legislative power by the legislature. Moreover, unlike legislation, such an exercise does not require the assent of Parliament. ${ }^{60}$

Treacy J went on in his judgment to find that the Crown cannot change unambiguous law by the exercise of prerogative powers, citing as authority for this the Case of Proclamations ${ }^{61}$ which found that: "The King by his proclamations or other ways cannot change any part of the common law, statute law, or customs of the realm." 62

The judgment concluded that if the ratification of an international treaty had the effect of altering domestic law then the Executive would be able to supplant the legislature by making legislation by the back door without any form of parliamentary consent or approval. ${ }^{63}$ This would, he argued: "clearly emasculate the constitutional principle that in the UK the Executive does not enjoy lawmaking powers unless these are bestowed upon it by Parliament". 64

In other words, the executive cannot make law unless it is first approved by the democratically elected (ergo democratically accountable) legislature - with judicial oversight upholding the supreme authority of the elected Parliament. ${ }^{65}$ A number of problems with this approach have been identified, however, creating what Morison and Livingstone have labelled as a constitutional crisis. ${ }^{66}$ In their view, the moving locus of power in the postmodern UK state has raised serious questions, for example, about the democratic or, indeed, accountable nature of many actions of an evermore amorphous executive. ${ }^{67}$

Significantly however, as Lord Steyn has pointed out, the doctrine of parliamentary sovereignty is itself a common law construct ${ }^{68}$ and is therefore open to judicial modification. Indeed, he went so far as to declare that:

The classic account given by Dicey of the doctrine of the supremacy of Parliament, pure and absolute as it was, can now be seen to be out of place in the modern United Kingdom. ${ }^{69}$

Lord Steyn went on to speculate that, were circumstances to arise where a sovereign Parliament sought, for example, to attempt to abolish judicial review, the courts would have to consider whether such an action was lawful. ${ }^{70}$

In the case in question (the challenge by the Countryside Alliance to the Hunting Act 2004), the House of Lords, as it happens, held unanimously that the Hunting Act was valid, notwithstanding that it was passed without the consent of the second chamber. ${ }^{71}$ The fact that the Hunting Act was passed in accordance with the requirements of the Parliament Acts of 1949 and 1911 ensured its "constitutionality". ${ }^{2}$ Five Law Lords did, however,

60 In the Matter of an Application by Caoimbin MacGiolla Cathain for Judicial Review [2009] NIQB 66, para. 33.

61 [1611] 12 Co Rep 74, at 75.

62 Ibid.

63 Ibid.

64 Ibid.

65 The case also, of course, highlights problems with the application of international law within the domestic context, see reference to McKerr at n. 45 above.

66 J Morison and S Livingstone, Reshaping Public Power: Northern Ireland and the British constitutional crisis (London: Sweet \& Maxwell 1995).

67 Ibid.

68 R (Jackson) v Attorney General [2006] 1 AC 262, para. 102.

69 Ibid.

70 Ibid.

71 Ibid., para. 39.

72 Ibid. 
expressly state that if the House of Commons alone were to try to delete from the 1911 Act the section which prevents it from extending the maximum permitted life of a Parliament beyond five years, that would not be a constitutional Act. ${ }^{73}$

It is also worth noting that, when the previous government was pushing another of its Asylum and Immigration Bills through Parliament, a provision which would have ousted the jurisdiction of the courts to hear challenges against decisions of the Immigration Appeal Tribunals was dropped following an outcry from, among others, the Lord Chief Justice, Lord Woolf. ${ }^{74}$ Similarly, proposals in the Legislative and Regulatory Reform Bill were also dropped on the grounds that they would have allowed ministers to do "all sorts of things that only an elected Parliament should be able to do". 75

What these cases appear to show is that among a number of Law Lords there has been a desire to flex some constitutional muscle in order to identify boundaries beyond which the executive and the legislature should not tread. The apparent willingness of courts within Northern Ireland to impose similar boundaries, as evidenced in a number of recent rulings, is therefore worth considering in more detail within the context of the broader debate on the protection of rights.

\section{Quashing the Sexual Orientation Regulations - the Christian Institute and the curate's egg}

One such ruling was delivered recently by the High Court in Northern Ireland. ${ }^{76}$ The case in question relates to an application for judicial review of the making of the Equality Act (Sexual Orientation) Regulations (Northern Ireland) 2006 by the Office of the First Minister and Deputy First Minister (OFMDFM). ${ }^{77}$ The applicants were various Christian organisations $^{78}$ and the respondent was the OFMDFM. There were, however, four interveners in the case: the Catholic Church (through the "Northern Bishops") in support of the applicants; and the Coalition on Sexual Orientation (COSO), the Equality Commission for Northern Ireland (ECNI) and the NIHRC, all in support of the respondent. ${ }^{79}$

The case arose following the publication by OFMDFM of a consultation document in July 2006 - Getting Equal: Proposals to outlaw discrimination on the ground of sexual orientation in the provision of goods and services in Northern Ireland. 80 The consultation period ran from 29 July 2006 to 25 September $2006,{ }^{81}$ the start date for consultation chosen to avoid "the twelfth fortnight" around 12 July. ${ }^{82}$ The closing date was determined by a desire to lay the Northern Ireland and Great Britain Regulations before Parliament at the same time. ${ }^{83}$ In the event, a decision was taken on 3 October 2006 to delay the proposals in Britain ${ }^{84}$ and the Northern

73 R (Jackson) v Attorney General [2006] 1 AC 262. See Lord Nicholls of Birkenhead, paras 57-9; Lord Steyn, para. 79; Lord Hope of Craighead, para. 118; Baroness Hale of Richmond, para. 164; Lord Carswell, para. 175; Lord Brown of Eaton-under-Heywood, para. 194.

74 See Dickson, "The role of judges", n. 51 above, at 350.

75 Ibid.

76 The Christian Institute and Others v The Office of the First Minister and Deputy First Minister [2007] NIQB 66.

77 Ibid., para. 1.

78 Ibid.

79 Ibid., paras 3 and 4.

80 Ibid., para. 12.

81 Ibid.

82 Ibid.

83 Ibid.

84 Ibid. 
Ireland Regulations were finally made on 8 November 2006, with analysis of the consultation published on 27 November 2006. ${ }^{85}$

The general position of the applicants was that the orthodox belief of Christians and of the other major world religions is that homosexual practice is sinful and that the regulations imposed on those who held such orthodox beliefs certain duties that were inconsistent with the practice of their religious faith. ${ }^{86}$ The applicants argued that they were not opposed to the principle of equality legislation relating to sexual orientation but they objected to the many aspects of the form of the legislation that had been adopted. ${ }^{87}$ In essence, the applicants and the Northern Bishops contended that there had not been equality of treatment between the anti-discrimination measures on the grounds of sexual orientation on the one hand and orthodox beliefs on the other. ${ }^{88}$ The respondents contended that the regulations relating to sexual orientation were designed to fill a significant and unsupportable gap in the framework of equality legislation and that the exemptions from the regulations which had been introduced for all religious groups achieved a fair balance between competing interests. ${ }^{89}$

Among the arguments put forward in the case by the applicants was that the OFMDFM had been in breach of its duty to act in a procedurally fair manner and/or in breach of the applicants' procedural legitimate expectations that they would be properly consulted about the content of the regulations. ${ }^{90}$ In particular, it was contended that the failure to consult properly manifested itself in: failing to allow sufficient time for the consultation period; failing to allow the standard minimum period of 12 weeks for the consultation period; providing the consultation period to fall during a period when many organisations would not be aware of the consultation exercise; and initiating a consultation exercise when the proposals were no longer at a formative stage. ${ }^{91}$

It was also contended that the OFMDFM had failed to carry out proper consultation by consulting upon proposals which were fundamentally different from those which the applicant believed to be the subject of the consultation exercise. ${ }^{92}$ The original consultation document had stated that the OFMDFM was "minded to accept that it is not appropriate to legislate for harassment within these Regulations" as future legislation was "a more appropriate vehicle" and would allow "more time to deal with the complex arguments". 93 However, the consultation paper did invite views and reasons for the inclusion of harassment provisions. ${ }^{94}$ Some consultees did subsequently advocate inclusion of harassment provisions in their responses to the consultation and the respondent accepted their arguments. ${ }^{95}$ Following legal advice, the harassment provisions were included in the regulations. ${ }^{96}$ The applicants contended, therefore, that there was a fundamental difference between the consultation paper and the final regulations. The respondent contended that the harassment section of the consultation document invited comment on the inclusion of

85 The Christian Institute and Others v The Office of the First Minister and Deputy First Minister [2007] NIQB 66.

86 Ibid., para. 8.

87 Ibid.

88 Ibid.

89 Ibid.

90 Ibid., para. 10 (a)

91 Ibid.

92 Ibid.

93 Ibid., para. 29.

94 Ibid.

95 Ibid.

96 Ibid. 
harassment in the regulations and that the introduction of the harassment provisions did not mean that anything had gone "clearly and radically wrong" with the consultation exercise.

In addition, it was argued that the OFMDFM had failed to take into account (or had given manifestly insufficient weight to) the consultation responses so that it breached its public law obligation conscientiously to take into account the product of consultation before finalising the draft of the regulations. ${ }^{97}$

\section{Fair and proper consultation}

The applicants' claim that they had a legitimate expectation of adequate consultation in relation to the making of the regulations ${ }^{98}$ was rejected by the court. ${ }^{99}$ Significantly, however, the applicants also contended that, even if there was no duty to consult the applicants in relation to the regulations, the respondent did engage in consultation and thereby was under a duty to consult properly. 100 The respondents' argument that the duty to consult properly only arose by concession was rejected by the court. The judgment referred to the comments of Auld LJ in the Court of Appeal in $R$ (Edwards) v Environment Agency 101 that: "It is an accepted general principle of administrative law that a public body undertaking consultation must do so fairly as required by the circumstances of the case."102

The court concluded that, once consultation is embarked upon, it must be carried out properly. ${ }^{103}$ The court also referred to the four requirements of consultation as stated in $\mathrm{R}$ (Coughlan) v North and East Devon Health Authority: 104

To be proper, consultation must be undertaken at a time when proposals are still at a formative stage; it must include sufficient reasons for particular proposals to allow those consulted to give intelligent consideration and an intelligent response; adequate time must be given for this purpose; and the product of consultation must be conscientiously taken into account when the ultimate decision is taken. ${ }^{105}$

Looking specifically at the consultation on the harassment provisions and the changes that had been made to the regulations from that which appeared in the original proposals, the court referred to R (Smith) v East Kent Hospital NHS Trust. ${ }^{106}$ In that case, the hospital trust had made recommendations to the Secretary of State for the reduction of services at a local hospital. ${ }^{107}$ The consultation document had suggested four options but, in the event, the proposal selected had a number of elements in common with all the options. ${ }^{108}$ Silber J stated that the concept of fairness should determine whether there was a need to re-consult if the decision-maker wished to accept a fresh proposal, but that the court should not be too liberal in the use of the power of judicial review to compel further consultation on any change. ${ }^{109}$ He concluded: "there should only be re-consultation if there is a fundamental

97 The Christian Institute and Others $\mathrm{v}$ The Office of the First Minister and Deputy First Minister [2007] NIQB 66, para. 10(b).

98 Ibid., para. 13.

99 Ibid., para. 18.

100 Ibid., para. 19.

101 [2006] EWCA Civ 877, para. 90.

102 Ibid.

103 Ibid.

104 [2001] QB 213, at para. 108

105 Ibid., para. 21.

106 [2002] EWHC 2640 (Admin), at para. 31.

107 Ibid.

108 Ibid.

109 Ibid. 
difference between the proposals consulted on and those which the consulting party subsequently wishes to adopt".

There was held to be no fundamental difference in the Smith case. ${ }^{110}$ It is also worthy of note that the respondent in the Christian Institute case also relied on $\mathrm{R}$ (Greenpeace Limited) $\mathrm{v}$ Secretary of State for Trade and Industry ${ }^{111}$ which involved a challenge to the decision to support nuclear new build as part of the United Kingdom's future electricity generating mix. ${ }^{112}$ There was found to be procedural unfairness, as the consultation document in that instance was manifestly inadequate. ${ }^{113}$ It contained no proposals as such and no information of any substance on the two issues of critical importance, namely the economics of new nuclear build and the disposal of nuclear waste. ${ }^{114}$ Sullivan J stated:

In reality, a conclusion that a consultation exercise was unlawful in the grounds of unfairness will be based upon a finding by the court, not merely that something went wrong, but that something went "clearly and radically" wrong. 115

In the Christian Institute case, the court went on to conclude that there was indeed an absence of proper consultation in relation to the harassment provisions. ${ }^{116}$ It pointed out that the consultation document was drawn in a manner that pointed to the issue of harassment on the grounds of sexual orientation being addressed by other means, and that the regulations "are fundamentally different from the scheme of the consultation paper". 117 The court concluded on this point that:

It was unfair to the consultees who agreed with the proposed deferral of harassment to induce them not to address their objections to the respondent and then to introduce harassment provisions. ${ }^{118}$

By reason of the finding of an absence of proper consultation, and taking into account the scope of the harassment provisions, the regulations were quashed. ${ }^{119}$

\section{Some possible implications of the Re Christian Institute judgment}

Looking at the judgment from the perspective of common law constitutionalism, there are a number of interesting elements worthy of note. For example, the court in this case had little difficulty in quashing the legislation, albeit that it was secondary in nature.

It is also noteworthy that the judgment devoted a not inconsiderable amount of focus to the procedural requirements on public bodies when it comes to consultation. While the court rejected the arguments about legitimate expectation of consultation in this instance, there was an interesting analysis of caselaw on this issue. The court referred, for example, to the comments of Stanley-Burnton $\mathrm{J}$ in $\mathrm{R}$ (BAPIO Action Limited and Others) $\mathrm{v}$ Secretary of State for the Home Department ${ }^{120}$ that:

On any basis, however, a duty to consult, if not expressly or impliedly imposed

by the legislation (and it is not suggested that there is any obligation necessarily

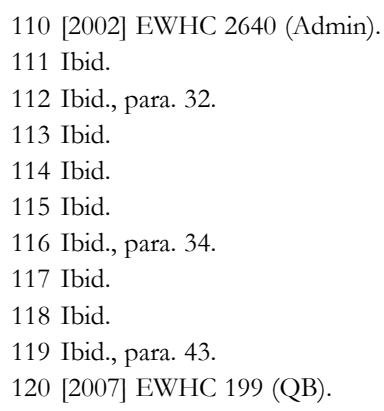


implied), must be based on special circumstances. One of those circumstances may be an established practice of prior consultation. ${ }^{121}$

Equally, while the court accepted that, generally, there had been proper consultation in this case (with the exception of the harassment provisions), the court very much set out its stall in terms of what is required from public authorities in relation to "proper consultation". This includes, as outlined above, that consultation must be undertaken at a time when proposals are still at a formative stage; it must include sufficient reasons for particular proposals to allow those consulted to give intelligent consideration and an intelligent response; adequate time must be given for this purpose; and the product of consultation must be conscientiously taken into account when the ultimate decision is taken. ${ }^{122}$ Furthermore, the court clearly stated that the duty to "consult properly" arises once there has been consultation - and not merely by concession. Moreover, the finding by the court that there was an absence of proper consultation on the harassment provisions due to the fact that the original proposals misled consultees is again, it is suggested, a significant finding.

Given the importance currently attached to consultation as a tool of participatory democracy, and indeed the centrality of consultation to other statutory provisions, ${ }^{123}$ the findings of the court in this case may well be useful in assisting further challenges to actions of the executive. Undoubtedly, however, the judgment is disappointing to those who would have benefited directly from the harassment provisions. The judgment is also clearly disappointing to organisations like the NIHRC and the Equality Commission who intervened in support of the harassment regulations. It is, however, respectfully suggested that from the point of view of these organisations and, indeed, from the point of view of other civil society NGOs, the judgment is something of a curate's egg, in that it is "good in parts". Unfortunately, the positive aspects to the ruling were ignored by both the NIHRC and the Equality Commission in the press releases they issued at the time, which both focused merely on the consequences of the quashing of the regulations from the perspective of the lesbian, gay, bisexual and transgendered communities. ${ }^{124}$ As such, the aspects of the ruling which related to the procedural requirements of proper consultation went unreported in terms of the wider discussion of the case in the media.

\section{Beyond the Christian Institute ruling}

The ruling in the Christian Institute case should also be considered alongside a number of other recent judgments in which the common law might be seen to have "punched its weight" in terms of delivering rights protection. The courts have continued to use the common law in order to ensure the fairness of the trial process, for example. Requa has pointed to the finding in Davis that measures aimed at maintaining anonymity of multiple witnesses were held to have undermined the ability of the accused to carry out an effective

121 [2007] EWHC 199 (QB), para. 17.

122 Ibid., para. 21

123 Northern Ireland Act 1998, s. 75, Sch. 9.

124 "Sexual Orientation Regulations ruling”, press release, NIHRC, 11 September 2007; "Equality Commission comment on the High Court decisions on the application for judicial review of the making of the Equality Act (Sexual Orientation) Regulations (Northern Ireland) 2006”, Equality Commission for Northern Ireland, 11 September 2007. 
defence and deprived the appellant of a fair trial. ${ }^{125}$ The common law principle that Lord Mance invoked in the Davis ruling was "a right to confrontation". 126

Regarding the right to liberty, it is worth noting the House of Lords' ruling in $R$ (Smith) $\mathrm{v}$ Parole Board. ${ }^{127}$ In this case, the Lords held that a failure on the part of the Parole Board to hold an oral hearing prior to revoking a licence, for a determinate sentence prisoner who had been released on licence, was a breach of the common law duty to act fairly. Also looking at the issue of prisoners' rights - although for those within prison rather than those released on licence - the common law again came to the rescue in $\mathrm{R}$ (Al-Hasan) $\mathrm{v}$ Home Secretary. ${ }^{128}$ In this case, the House of Lords found that a prison governor had breached the common law principle of natural justice regarding the disciplining of prisoners who had refused to submit to a squat search.

Within the context of the particular circumstances of Northern Ireland, other examples of the common law being used to curtail abuses of executive power include the ruling in the challenge to the appointment of Bertha McDougall as the interim victims' commissioner. ${ }^{129}$ In this case, no less than 67 questions were laid out for referral to the Attorney General with regard to protecting the due administration of justice. The judgment cited the common law offence to pervert or obstruct the course of justice and contempt of court. ${ }^{130}$

This is not to suggest that the performance of the common law in upholding the protection of rights is entirely favourable. Indeed, sceptics may well point to the willingness of the courts in the Christian Institute and MacGiolla Cathain cases above to strike down legislation designed to provide protection against discrimination on grounds of sexual orientation while upholding a law that directly discriminates against Irish language speakers. Furthermore, the ruling of the Law Lords in cases like McKerr, along with recent critical comments from Lord Hoffmann ${ }^{131}$ about the NIHRC, may well lead those sceptical about the role of the judiciary in protecting rights to argue that they have much to be sceptical about. Critics might also point to rulings such as $R \mathrm{v}$ Chief Constable of the $R U C$, ex parte Begley in which the Lords rejected the notion that the common law recognises a right for a suspect to have a solicitor present during a police interview as further evidence of the failure of the common law to deliver the goods when it comes to protecting rights. ${ }^{132}$ Similarly, sceptics are likely to be further bolstered by a number of cases in which the common law failure to protect rights has been challenged by the European Court of Human Rights. In HL v United Kingdom, for example, the Strasbourg court found that there had indeed been a violation of Article 5 of the ECHR. ${ }^{133}$ Previously, the House of Lords had ruled that the detention of a mentally ill patient at a hospital was justified on the common law doctrine of necessity. ${ }^{134}$

125 M Requa, "Hearsay, human rights and judicial dialogue: Article 6(3)(d) in UK courts" (2010) Autumn International Journal of Evidence and Proof, forthcoming.

126 Ibid. See also R v Davis (Iain) [2008] UKHL 36; [2008] 3 WLR 125.

127 [2005] UKHL 1.

128 [2005] UKHL 13.

129 Re Downes Application [2006] NIQB 79.

130 Ibid., para. 4.

131 Re E's Application [2006] NICA 37.

132 [1997] 1 WLR 1475.

133 HL $\mathrm{v}$ UK (2004) 40 EHRR.

134 R v Bournewood Community and Mental Health NHS Trust, ex parte L [1999] 1 AC 458. 
The situation is, of course, further complicated when one considers ways in which rights claims may conflict. In $R v$ Connor, the Law Lords had to address the issue of whether the common law prohibition on the admission of evidence of the jury's deliberation prevailed even if the Court of Appeal was presented with a statement from a juror which, if admitted, would provide prima facie evidence of jury partiality in breach of Article 6 of the ECHR. ${ }^{135}$ Dismissing the appeal, Lord Steyn did nevertheless acknowledge that in certain cases the court does have the power to admit evidence about the deliberations of the jury in order to prevent injustice. ${ }^{136}$ Indeed, one section of his speech captures well the essence of the common law itself:

The common law rule is a judge made rule. Where the reason for a judge made rule stops, it may be appropriate to qualify its reach. Where a new situation arises which was never previously considered the scope of the rule may be reconsidered ... So far as judges have propounded a rule which, in the light of experience, is potentially productive of injustice, it is not beyond their power to put the matter right. ${ }^{137}$

One could undoubtedly speculate at length about the extent to which judge-made rules may, or may not, be an adequate mechanism for ensuring the protection of rights. That is not, however, the purpose of this article. The point here is not that judges should be left to protect human rights in place of a Bill of Rights. Neither is this article arguing that there should be an attempt to recast proposals for a Bill of Rights for Northern Ireland which would include common law rights. My aim is merely to argue that the value of the common law in protecting rights should be acknowledged within the wider deliberations around a Bill of Rights.

\section{Conclusions}

One might, of course, question whether it matters that consideration of common law rights or the wider UK-wide debate about judicial activism are absent from the Northern Ireland Bill of Rights debate. It is respectfully suggested that there are indeed a number of serious problems with the current approach and it is to these that we now turn.

First, it is worth noting that one of the central points of contention with regard to the current Bill of Rights debate in Northern Ireland is the extent to which any such Bill might curtail the authority of elected politicians. In a speech to delegates at the World Bar Conference, for example, the First Minister of Northern Ireland stated that he was:

wary of an over-extensive Bill of Rights which could usurp the role of democratically elected politicians and push judges into the political spotlight ... Let politicians make laws - even at times bad laws - and be accountable for them to the electorate, rather than leaving important decisions to those who have no democratic mandate. ${ }^{138}$

Such arguments have, in fact, been around as long as the Bill of Rights debate has itself. ${ }^{139}$ What is significant is that these arguments, certainly when put forward by politicians, tend to assume that the relationship between the judiciary, the legislature and the executive is presently a fixed one, with definite and identifiable boundaries. As this article has noted, however, there is at the moment a "fierce and prolific debate" taking place within the UK about the current limits of judicial power, including the extent to which the notion of parliamentary sovereignty

135 [2004] UKHL 2.

136 Ibid.

137 Ibid., para. 17.

138 "Northern Ireland First Minister and DUP Leader, Rt Hon. Peter Robinson MP MLA, addresses delegates at the 2008 World Bar Conference", press release, 30 June 2008, www.dup.org.uk/.

139 Murray, "The importance of a Bill of Rights", n. 41 above. 
itself may be open to modification by the judiciary. Set within the context of a judiciary operating without fixed and definite boundaries, one might view a Bill of Rights for Northern Ireland therefore as an opportunity for clarifying current constitutional ambiguities, rather than simply delivering an additional layer of judicial authority.

Another problem with the approach to the Bill of Rights debate to date, particularly with respect to the advice submitted to the Secretary of State by the NIHRC, relates to misunderstandings which may arise about current legal protections available in Northern Ireland. If a right or principle which is already accepted as part of the common law is not named as such, but rather is presented as a proposal which emanates solely from "international standards", then the perception may well be created that the right does not presently exist anywhere in domestic law. It may well be that this was a deliberate tactic in order to "over-emphasise" the need for a Bill of Rights by downplaying existing protections. If that was the case, then it is suggested that this was a mistaken approach. Given the emphasis that has been placed on the Bill of Rights deliberations as an educative process, ${ }^{140}$ one might conclude that it is a process which has misled quite a number of participants about an important area of rights protection.

In addition to the misinformation aspect of the debate, there is another difficulty which is more insidious. If rights protection is to be measured in terms of the volume of international instruments which have been successfully incorporated into domestic law, then genuine advances in rights protection that take place within the realm of common law may be overlooked, simply because they do not fit into what has become a conventional rights protection narrative. Such a problem may not be confined to the Bill of Rights project, but could spill over into other areas of the NIHRC's work. Indeed, it is suggested that this has already happened, as evidenced by the response to the ruling in the Christian Institute case, where a number of positive aspects of the judgment were overlooked by both the Equality Commission and the NIHRC. It is also worth noting that a visit to the NIHRC website reveals a section entitled "Your Rights". Unfortunately, the rights in question relate solely to those contained in the Human Rights Act 1998. ${ }^{141}$

\section{A new way forward?}

It has become something of a cliché about the Bill of Rights process in Northern Ireland that it is too important to be left to one narrow group or organisation in society, including the NIHRC. ${ }^{142}$ The irony is that one might now argue that the deliberative process around this issue has, in fact, largely omitted the contribution of one key institution in society namely the courts. International standards for human rights have much to offer those seeking protection from rights abuses - but so do domestic courts. What the domestic courts say about a right to consultation, or a right to confrontation, is as relevant - if not more so - as the findings of UN treaty-monitoring bodies. It is vital that those seeking to promote and protect rights are aware of all the tools at their disposal - including those advances which common law constitutionalism has to offer.

In terms of recommendations for the way forward, it is suggested that one starting point might be a wider consideration of those rules and principles developed by judges as part of the common law for protecting rights, since this is the area that would appear to be most neglected to date. This might include an event, sponsored perhaps by the NIHRC, which seeks to move judicial rights protection on to the radar of Northern Ireland's human

140 Murray, "The importance of a Bill of Rights", n. 41 above.

141 www.nihrc.org/.

142 Harvey, "The implementation of a Bill of Rights", n. 30 above, at 368. 
rights community and, indeed, civil society generally. In such a scenario, aspects of judgments in cases such as those involving the Christian Institute, Brenda Downes, the Countryside Alliance and others could be "dusted off" and used to examine how rights protection could be developed by strategically litigating in certain areas.

In this context, it is worth noting that the remit of the NIHRC extends beyond proposals for a Bill of Rights for Northern Ireland. The NIHRC is required, for example, to keep under review the adequacy and effectiveness in Northern Ireland of "law and practice relating to the protection of human rights". ${ }^{143}$ The NIHRC is also required to promote understanding and awareness of the importance of human rights in Northern Ireland and, for this purpose, it may undertake, commission or provide financial or other assistance for research and educational activities. ${ }^{144}$ Certainly, there is little doubt that highlighting ways in which the common law might be used to further rights protection in Northern Ireland would fall within this broader remit.

Looking beyond the NIHRC to the wider human rights community in Northern Ireland, it is suggested that any stasis in legislating for a Bill of Rights for Northern Ireland should be viewed as an opportunity for the courts to become the focus of attention in terms of pushing forward a broader rights agenda. The attraction of this approach from the campaigner's perspective is that advancement of rights protection within the courts (through greater use and awareness of common law rights) and continued campaigning for a strong and inclusive Bill of Rights are not mutually exclusive. The attraction for the judiciary is that such a scenario would provide an even wider opportunity for it to demonstrate the freshness and sophistication of judicial reasoning that has hitherto eluded many within the human rights community. Again, the point here is not that campaigners should be forced to abandon their efforts to seek a Bill of Rights for Northern Ireland, but rather that they should not put all their eggs in the Bill of Rights basket.

In this context, it is worth considering Harvey's argument ${ }^{145}$ that, in addition to legislating for a Bill of Rights, a multiplicity of mechanisms and strategies (including those of an educational variety) are essential to achieving the goal of a human rights culture in Northern Ireland. It would seem that the hour has perhaps arrived for common law constitutionalism to be acknowledged as having some contribution to make in developing that culture.

143 Northern Ireland Act 1998, s. 69(1).

144 Ibid., s 69(6).

145 Harvey, "The implementation of a Bill of Rights", n. 30 above, at 371. 